\title{
Change in species composition of vegetation on various-aged set-aside lands of the Volga Delta
}

\author{
Artem Sokolov ${ }^{1, *}$, Galina Sokolova $^{1}$, Shamil Bairambekov ${ }^{1}$, and Tamara Boeva ${ }^{1}$ \\ ${ }^{1}$ Federal State Budgetary Scientific Institution, 416251, Astrakhan region, Chernoyarsk District, \\ Village Solenoe Zaimishte, Northern Quarter, 8, Russia
}

\begin{abstract}
The object of the present research is set-aside lands of various ages. The study was aimed to identify the main biological groups of weed growing on set-aside lands of the Volga Delta, which were removed from production in different years. Within the study, species composition of setaside lands' vegetation was defined, which amounted to 28 species and 16 families. The plant community of set-aside lands includes such large families as Asteraceae (5 species), Poaceae (4 species), Brassicaceae (3 species). It was observed that quantitative species composition of set-aside lands' flora has been changing depending on its age: the older a set-aside land is, the less species grow there. In spring and summer seasons, ephemeral, annual and biennial weeds prevailed, while in autumn perennial plants did: the latter were estimated of $75-80 \%$, their wet weight amounted up to $70-92 \%$ of total weight due to the plentiful growth and development of a perennial rhizome plant named Phragmites australis (Cav.) Trin. ex Steudel. The research has lasted for 10 years and allowed observing a 14$32 \%$ increase in a number of plants belonging to a xerophyte group on longstanding set-aside lands with low level of soil moisture. Agroecosystems of various-aged set-aside lands hosted the development of flora having different vegetative weight that is capable of accumulating solar energy. Significant amount of accumulated energy reduced the entropy of the environment and improved its ecological state. On an old-aged setaside land, corps of perennial plants vegetating for a long time have been maximally accumulating energy and gained $25712.42 \mathrm{MJ} / \mathrm{ha}$.
\end{abstract}

\section{Introduction}

Agricultural lands traditionally hold a priority place in the land legislation of the Russian Federation. Russia is interested in maintaining a high level of development of agricultural production that allows increasing the country's independence of food imports and thereby ensuring its national security. Constantly growing demand for food can be supplied by ecological intensification of agriculture, which can reduce the negative impact on the environment [1]. As of January 1, 2019, the total area of lands used for agricultural purposes in the Astrakhan Region was 3631.8 thousand ha, the total area of cultivated lands was 2978.1 thousand ha, which included: arable lands - 276.9 thousand ha; hayfields -

\footnotetext{
* Corresponding author: sspmaster@mail.ru
} 
372.5 thousand ha; pastures - 2316.4 thousand ha; set-aside lands -7.1 thousand ha; perennial plantations - 5.2 thousand ha. According to the Decree of the Government of the Astrakhan Region dated November 26, 2014 № 541-P, the Ministry of Agriculture and Fishing Industry of the Astrakhan Region was conferred with power to elaborate measures aimed at introducing undeveloped land parcels into agricultural production and ensuring the fertility of agricultural lands. Anthropogenic impact on the natural environment causing changes in species diversity requires effective measures to preserve the environment [2]. Many authors assume that defining feasibility and finding a way of returning set-aside lands back to agricultural production demand the preliminary determination of flora species composition of those lands, evaluation of fertility level according to agrophysical and agrochemical indicators, and educing of morphological changes in soils [3-6]. Yet former studies on set-aside lands are quite sufficient, this fact does not reduce the relevance of the problem, since most works do not contain analysis of modern processes based on a holistic study of zonal and regional features [7]. The authors suppose that the succession of vegetation can be an indicator of environmental changes [8-9]. Effective use of set-aside lands is relevant to a different extent for any country of the world [10].

The research is aimed to identify the main biological groups of weed vegetation on set-aside lands of the Volga Delta, removed from agricultural production in different years.

\section{Research tasks}

- to identify the species composition of flora on set-aside lands of various ages;

- to detach ecological groups of vegetation under various moisture conditions;

- to study the influence of lands' set-aside standing on the ecological function of its agro-ecosystem;

- to perform a comparative analysis of a succession process of a weed-field component on set-aside lands, taking into account previous research performed by the authors.

\section{Materials and methods}

The studies were carried out in 2018-2019 on a research farm named "Opytnoye pole" that belongs to the All-Russian Scientific Research Institute of Irrigated Vegetable and Melon Growing, which is a branch of the Federal State Budget Scientific Educational Institution "Scientific and Practical Center for Scientific Research". The territory of this farm is located in a semi-desert climatic zone which has a strong continental climate. The average annual rainfall is $160 \mathrm{~mm}$, which is not enough to cultivate crops without irrigation. In the past century, a reclamation (irrigation) system with underground drainage was built on a leveed farm territory for growing both vegetable and melon crops under various types of sprinkling irrigation (Fregat, DDA-100MA). The research farm has alluvial-meadow medium-heavy loamy soil that contains 1.5-4.0\% of humus (according to the Tyurin method), $60-130 \mathrm{mg} / \mathrm{kg}$ of hydrolysable nitrogen (according to Kornfield), 30-60 mg/kg of mobile phosphorus (according to Machigin) and $250-400 \mathrm{mg} / \mathrm{kg}$ of exchangeable potassium (according to Machigin). The reaction of soil solution is $\mathrm{pH}-7.4-7.6$. The hydrological network of the farm is represented by the Kizan, Kigach, Krutoberezhnaya and Sukhaya Tabola rivers. During freshets, all hollow places are flooded. Freshet waters affect the soil water regime, changes the dynamics of soluble salts in the soil and the level of groundwater that occurs at a depth of 2.5-3.5 m. The chloride-sulfate type of salinization predominates. Precipitation poorly affects groundwater, since significant part of rainwater is subject to rapid evaporation.

Period from April to September is the time for field work lasting from the beginning of plant vegetation to its end. Uneven aged set-aside lands are the objects of the present study. The same object was examined several times during one season (in spring examination took place in May, summer - July, autumn - September), taking into account the seasonal 
rhythm of development of various species. The flora was studied using a method that consists in comparing floristic data collected at the same site divided into sections with timespans of 10 years.

3 sections of set-aside land site were examined:

1. Short-standing set-aside land: an 8-9 year-old one with an area of 16.2 ha. During 2007-2009 it was surveyed as a 1-3-year-old fallow land; in 2010 it was planted with feeding crops; since 2011 this site has been a set-aside land.

2. Middle-standing set-aside land: a 16-17 year-old one with an area of 18.3 ha; during 2007-2009 it was surveyed as a 5-7-year-old set-aside land.

3.Longstanding set-aside land: a 24-25 year-old one with an area of 22.4 ha; during 2007-2009 it was surveyed as a 13-15-year-old set-aside land.

The extent of weed growing at the site was determined by applying a frame $(0.5 \times 0.5$ $\mathrm{m}, \mathrm{S}=0.25 \mathrm{~m}^{2}$ ), this experiment was replicated twelve times. The following parameters were determined: species composition of weeds; biological type of weeds; amount by counting stems (for perennial plants) and items (for annual and biennial plants); wet weight of weeds; weed development phase; height of weeds by measuring plants in their natural occurrence without stretching. Several medium-sized samples were examined growing in different distinctive places of the land parcel.

An anti-entropy function of the plant gene resource was formed according to two levels: 1) productivity 2) period and time of vegetation. This function consists in creating conditions for the fullest energy use and accumulation in crops of fodder weed grasses. It was determined through the amount of accumulated energy.

\section{Results}

A set-aside land is commonly understood as an agricultural land that has not been seeded or planted with agricultural crops or remained fallow for more than a year. The diversity of species composition on set-aside lands depends on many factors: climatic, environmental, agrotechnical, etc. For effective targeted use of such lands, an analysis of the current state is required that involves addressing the issues of plant geography: species composition, dominance, abundance of species, quantitative and qualitative ratio of species composition of a plant community. Plant communities reflect the existing ecological situation [11-14].

The first study on the short-standing set-aside land that was performed in spring showed that a species composition of weeds was represented mainly by the following two spring ephemeral plants: Eremopyrum triticeum (Gaertner) Nevski and Bromus squarrosus L. The amount of stems with a height of 0.12-0.08 m was 251-52 pcs $/ \mathrm{m}^{2}$ with wet weight of 104 and $12 \mathrm{~g} / \mathrm{m}^{2}$ respectively. Then Atriplex aucheri Moq $\left(27 \mathrm{pcs} / \mathrm{m}^{2}-32 \mathrm{~g} / \mathrm{m}^{2}\right)$, Setaria viridis (L.) Beauv. (21 pcs $\left./ \mathrm{m}^{2}-18 \mathrm{~g} / \mathrm{m}^{2}\right)$ and Galium aparine L. $\left(13 \mathrm{pcs} / \mathrm{m}^{2}-30 \mathrm{~g} / \mathrm{m}^{2}\right)$ should be pointed out among annual and biennial plants at the stage of booting. Thlaspi arvense L. ( 9 $\left.\mathrm{pcs} / \mathrm{m}^{2}-23 \mathrm{~g} / \mathrm{m}^{2}\right)$, Polygonum aviculare L. $\left(8 \mathrm{pcs} / \mathrm{m}^{2}-5 \mathrm{~g} / \mathrm{m}^{2}\right)$, Tragopogon orientalis L. (7 $\left.\mathrm{pcs} / \mathrm{m}^{2}-12 \mathrm{~g} / \mathrm{m}^{2}\right)$ and Polycnemum arvense L. $\left(6 \mathrm{pcs} / \mathrm{m}^{2}-10 \mathrm{~g} / \mathrm{m}^{2}\right)$ belonging to this biological group were presented in small amounts at the stage of booting; Cannabis ruderalis Janisch. (2 pcs $\left./ \mathrm{m}^{2}-11 \mathrm{~g} / \mathrm{m}^{2}\right)$ was presented at the stage of seedling. Wintering annual plants occupying a significant part of the investigated area were presented at the flowering stage by Chorispora tenella (Pallas) DC. $\left(45 \mathrm{pcs} / \mathrm{m}^{2}-34 \mathrm{~g} / \mathrm{m}^{2}\right)$, Lamium amplexicaule L. (32 pcs $\left./ \mathrm{m}^{2}-18 \mathrm{~g} / \mathrm{m}^{2}\right)$, Descurainia sophia (L.) Webb ex Prantl. (18 pcs $/ \mathrm{m}^{2}-$ $\left.17 \mathrm{~g} / \mathrm{m}^{2}\right)$ and Fumaria schleicheri Soy. $\left(15 \mathrm{pcs} / \mathrm{m}^{2}-6 \mathrm{~g} / \mathrm{m}^{2}\right)$.

The group of perennials included two species of weeds with the largest number and wet weight of stems: Galium humifusum Bieb. $\left(54 \mathrm{pcs} / \mathrm{m}^{2}-48 \mathrm{~g} / \mathrm{m}^{2}\right)$ and Acroptilon repens (L.) DC. $\left(42 \mathrm{pcs} / \mathrm{m}^{2}-30 \mathrm{~g} / \mathrm{m}^{2}\right)$. The following species of perennial weeds were behind the ones above in terms of parameters under the study: Artemisia austriaca Jacq. (24 pcs $/ \mathrm{m}^{2}-46$ 
$\left.\mathrm{g} / \mathrm{m}^{2}\right)$, Dodartia orientalis L. (19 pcs $\left./ \mathrm{m}^{2}-46 \mathrm{~g} / \mathrm{m}^{2}\right)$, Lactuca tatarica (L.) C.A. Meyer (16 $\mathrm{pcs} / \mathrm{m}^{2}-23 \mathrm{~g} / \mathrm{m}^{2}$ ) and Phragmites australis (Cav.) Trin. ex Steudel (13 pcs $\left./ \mathrm{m}^{2}-44 \mathrm{~g} / \mathrm{m}^{2}\right)$. The rest of weed species belonging to this group: Convolvulus arvensis L., Alhagi pseudalhagi (Bieb.) Desv., Sonchus arvensis L., and Glycyrrhiza glabra L. - were presented on set-aside lands in small amounts (from 3 to $7 \mathrm{pcs} / \mathrm{m}^{2}$ ). In contrast to Convolvulus arvensis L. and Sonchus arvensis $L$. with their little wet weight $\left(7-9 \mathrm{~g} / \mathrm{m}^{2}\right)$, other plants listed above had wet weight of $23-33 \mathrm{~g} / \mathrm{m}^{2}$ (table 1).

In summer, all spring ephemeral plants shifted to the stage of maturity and cast of seeds. The short-standing set-aside land had Atriplex aucheri Moq $\left(36 \mathrm{pcs} / \mathrm{m}^{2}\right)$, Galium aparine L. (12 pcs $\left./ \mathrm{m}^{2}\right)$, Polygonum aviculare L. $\left(7 \mathrm{pcs} / \mathrm{m}^{2}\right)$, Polycnemum arvense L. $\left(5 \mathrm{pcs} / \mathrm{m}^{2}\right)$ at the booting stage and Cannabis ruderalis Janisch. $\left(1 \mathrm{pcs} / \mathrm{m}^{2}\right)$ at the flowering stage. The majority of perennial species entered the flowering stage: Alhagi pseudalhagi (Bieb.) Desv., Convolvulus arvensis L., Lactuca tatarica (L.) C.A. Meyer, Sonchus arvensis L., Artemisia austriaca Jacq., Glycyrrhiza glabra L., Phragmites australis (Cav.) Trin. ex Steudel. Rhizome perennial plants named Cynanchum acutum L. that had cropped up on the setaside land in early June in the amount of $2 \mathrm{pcs} / \mathrm{m}^{2}$ passed to the booting stage and started blossoming.

Table 1. Species composition and extent of weed growing on short-standing set-aside,

(springs of 2018-2019).

\begin{tabular}{|c|c|c|c|c|}
\hline Weed species & Family & $\begin{array}{c}\text { Amount } \\
\text { of stems, } \\
\mathrm{pcs} / \mathrm{m}^{2}\end{array}$ & $\begin{array}{c}\text { Stem } \\
\text { height, } \\
\mathrm{m}\end{array}$ & $\begin{array}{c}\text { Wet } \\
\text { weight, } \\
\mathrm{g} / \mathrm{m}^{2}\end{array}$ \\
\hline 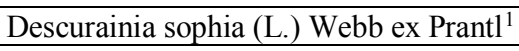 & Brassicaceae & 18 & 0.09 & 17 \\
\hline Fumaria schleicheri Soy ${ }^{1}$ & Fumarioideae & 15 & 0.06 & 6 \\
\hline Chorispora tenella (Pallas) DC. ${ }^{1}$ & Brassicaceae & 45 & 0.19 & 34 \\
\hline Lamium amplexicaule L. ${ }^{1}$ & Lamiaceae & 32 & 0.09 & 18 \\
\hline Fumaria schleicheri Soy. ${ }^{2}$ & Chenopodiaceae & 6 & 0.13 & 10 \\
\hline Polygonum aviculare L. ${ }^{2}$ & Polygonaceae & 8 & 0.09 & 5 \\
\hline Tragopogon orientalis $\mathrm{L}^{2}$ & Asteraceae & 7 & 0.26 & 12 \\
\hline Cannabis ruderalis Janisch. $^{2}$ & Cannabaceae & 2 & 0.12 & 11 \\
\hline Bromus squarrosus L. ${ }^{2}$ & Poaceae & 52 & 0.08 & 12 \\
\hline Atriplex aucheri Moq. ${ }^{2}$ & Chenopodiaceae & 27 & 0.24 & 29 \\
\hline $\begin{array}{l}\text { Eremopyrum triticeum (Gaertner) } \\
\text { Nevski }^{2}\end{array}$ & Poaceae & 251 & 0.12 & 114 \\
\hline Galium aparine $\mathrm{L}^{2}$ & Rubiaceae & 13 & 0.08 & 37 \\
\hline Setaria viridis (L.) Beauv. ${ }^{2}$ & Poaceae & 21 & 0.10 & 14 \\
\hline Thlaspi arvense L. ${ }^{2}$ & Brassicaceae & 9 & 0.09 & 23 \\
\hline Alhagi pseudalhagi (Bieb.) Desv. ${ }^{3}$ & Fabaceae & 4 & 0.16 & 27 \\
\hline Convolvulus arvensis L. ${ }^{3}$ & Convolvulaceae & 3 & 0.04 & 7 \\
\hline Acroptilon repens (L.) DC. ${ }^{3}$ & Asteraceae & 42 & 0.13 & 30 \\
\hline Dodartia orientalis L. ${ }^{3}$ & Scrophulariaceae & 19 & 0.18 & 46 \\
\hline Lactuca tatarica (L.) C.A. Meyer ${ }^{3}$ & Asteraceae & 16 & 0.08 & 23 \\
\hline Sonchus arvensis L. ${ }^{3}$ & Asteraceae & 6 & 0.12 & 9 \\
\hline
\end{tabular}




\begin{tabular}{|c|c|c|c|c|}
\hline Galium humifusum Bieb. $^{5}$ & Rubiaceae & 54 & 0.09 & 48 \\
\hline Artemisia austriaca Jacq. $^{4}$ & Asteraceae & 24 & 0.07 & 46 \\
\hline Glycyrrhiza glabra L. $^{5}$ & Fabaceae & 7 & 0.31 & 33 \\
\hline $\begin{array}{c}\text { Phragmites australis (Cav.) Trin. ex } \\
\text { Steudel }\end{array}$ & Poaceae & 13 & 0.33 & 44 \\
\hline Totally & - & 694 & - & 655 \\
\hline
\end{tabular}

Note: 1 - wintering annual plant; 2 - spring annual plant; 3 - root sucker perennial plant; 4 taproot perennial plant; 5 -rhizome perennial plant.

The accountancy performed in autumn showed that the following species of spring annuals remained on the set-aside at the stage of seed maturity and cast: Atriplex aucheri Moq. (22 pcs $\left./ \mathrm{m}^{2}-92 \mathrm{~g} / \mathrm{m}^{2}\right)$, Setaria viridis (L.) Beauv. (12 pcs $\left./ \mathrm{m}-26 \mathrm{~g} / \mathrm{m}^{2}\right)$, Galium aparine L. $\left(11 \mathrm{pcs} / \mathrm{m}^{2}-67 \mathrm{~g} / \mathrm{m}^{2}\right)$, Polygonum aviculare L. $\left(5 \mathrm{pcs} / \mathrm{m}^{2}-36 \mathrm{~g} / \mathrm{m}^{2}\right)$, Fumaria schleicheri Soy. $\left(3 \mathrm{pcs} / \mathrm{m}^{2}-49 \mathrm{~g} / \mathrm{m}^{2}\right)$ and Thlaspi arvense L. $\left(2 \mathrm{pcs} / \mathrm{m}^{2}-31 \mathrm{~g} / \mathrm{m}^{2}\right)$. Among the perennials, some samples of Convolvulus arvensis L., Cynanchum acutum L. and Lactuca tatarica (L.) CA Meyer continued blossoming, one of the latter plants was observed to have seedlings, while the bulk of weeds had passed into the seed maturity stage by that time.

In spring, the vegitation species composition on the medium-standing set-aside, was similar to the species composition on a short-standing set-aside, but the total number of plant stems was 1.5 times smaller, and the wet weight of weeds was 1.1 times higher than the weight of weed growing on a short-standing set-aside. The reason was a perennial rhizome plant growing and developing on a set-asite parcel: Phragmites australis (Cav.) Trin. ex Steudel. Shrubs and trees named Tamarix ramosissima Ledeb., Elaeagnus angustifolia L. and Ulmus laevis Pallas with a hieght of 1.5 to 5-6 $\mathrm{m}$ have grown along the former temporary irrigators and on the set-aside parcel.

In spring, the total number of annuals', biennials' and perennials' stems on the longstanding set-aside was 2.0 times smaller than on the short-standing set-aside and 1.3 times smaller than on the medium-standing set-aside. The summer survey revealed that a significant part $(76.3 \%)$ of total wet weight of weed $\left(1217 \mathrm{~g} / \mathrm{m}^{2}\right)$ accounted for Phragmites australis (Cav.) Trin. ex Steudel.

Shrubs and trees of the following species have independantly grown on the set-aside land during a twenty-five year period: Tamarix ramosissima Ledeb., Elaeagnus angustifolia L. and Ulmus laevis Pallas with a height of 1.5 to 7-12 m.

All plants are conditionally divided into four groups according to their demand for water: xerophytes, mesophytes, hydrophytes and hygrophytes, but there are some plants ranking intermediate positions. Over a ten-year period (from 2009 to 2019), the water consumption groups changed the following way: on a short-standing set-aside parcel the xerophytic group reduced by $18 \%$, since some species disappeared and number of specimens of other species decreased (Eremopyrum orientale (L.) Jaub., Bromus tectorum L.), the group of xeromesophytes reduced by $13 \%$ (due to the disappearance of Chenopodium album L., Persicaria amphibia, Limonium sinuatum, Zygophyllum fabago L.), while the number of weeds in the mesophyte group (Fumaria schleicheri Soy, Descurainia sophia (L.) Webb ex Prantl, Galium humifusum Bieb.) increased by $25 \%$. On the medium- and long-standing set-asides with low soil moisture, the reduction in the number of specimens primarily concerned species belonging to medium-moistened groups: xeromesophytes and mesophytes. The xerophytic group experienced an increase in the number of weeds by $32 \%$ and $14 \%$ (Alhagi pseudalhagi (Bieb.) Desv., Glycyrrhiza glabra L., Acroptilon repens (L.) DC., Galium humifusum Bieb., Dodartia orientalis L.), as well as the group of hygrophytes - by $5 \%$ and $12 \%$, respectively, due to an increase in the number of stems of Phragmites australis (Cav.) Trin. ex Steudel. 
Constant energy consumption is an essential condition and the most important sign of life for autotrophs. The forms of energy existing in nature are characterized by the corresponding values of entropy. The lower the value of entropy per unit of energy, the higher the quality of this energy, so that its ability to perform work increases. Entropy is an essential phenomenon for understanding the course of natural processes, since it indicates directions of their possible proceeding. When energy decreases in a system, entropy increases. Entropy is a measure of energy that cannot be applied anyhow. The general physical law of minimum energy dissipation is important for ecology. Under the absence of a plant gene resource, entropy of the environment can increase (under certain conditions), because part of solar energy is dissipated so that not used by the plant. The anti-entropic (ecological) function consists in creation of conditions for the most efficient use of energy and its accumulation in crops. This function can be determined through the amount of this energy $[15,16]$. Within the studies on the short-standing set-aside parcel (aged 8-9 years), the largest number of weeds grew during the vegetation season $-694 \mathrm{pcs} / \mathrm{m}^{2}$ in spring; 572 $\mathrm{pcs} / \mathrm{m}^{2}$ in summer and $217 \mathrm{pcs} / \mathrm{m}^{2}$ in autumn. With an increase in the age of the set-aside land to 16-17 years, the total number of weeds 1.5-1.6-1.2 times decreased, respectively; when the age was over 24-25 years, weed decreased by 2.0-1.3 times (Figure 1, Figure 2).

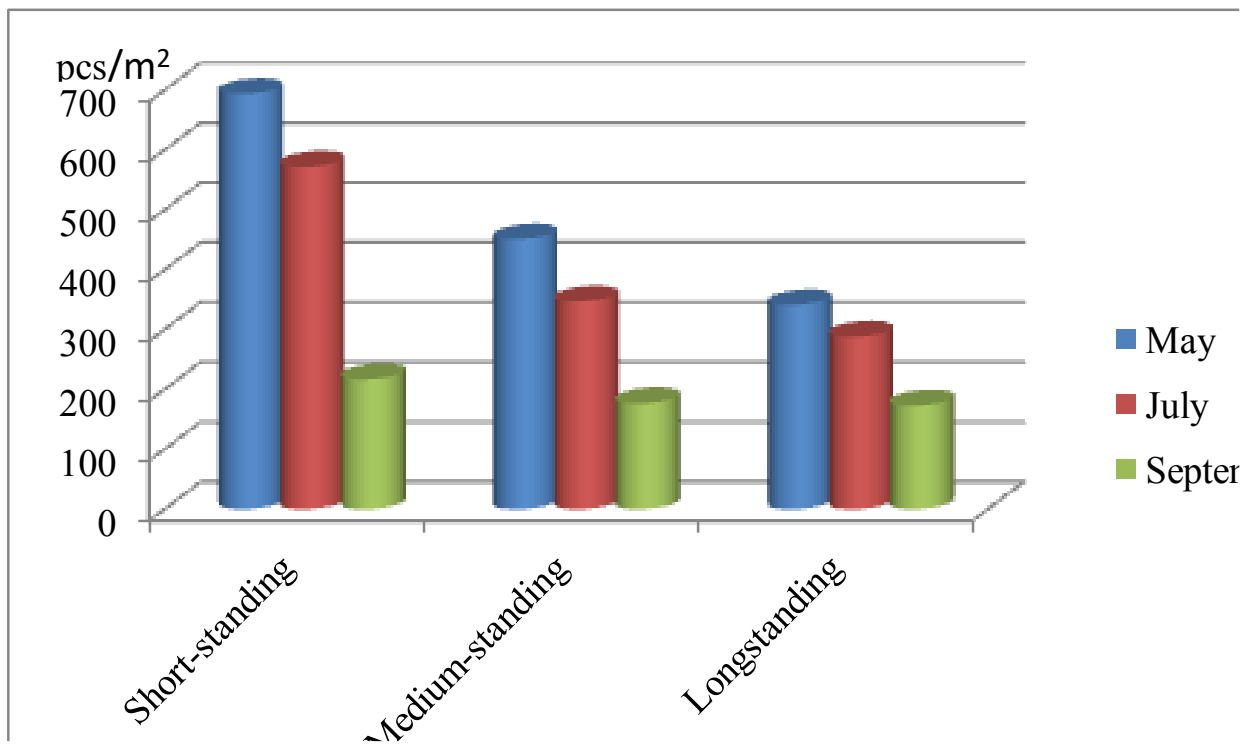

Fig. 1. The total number of stems on set-asides of various ages, $\mathrm{pcs} / \mathrm{m}^{2},(2018-2019)$. 


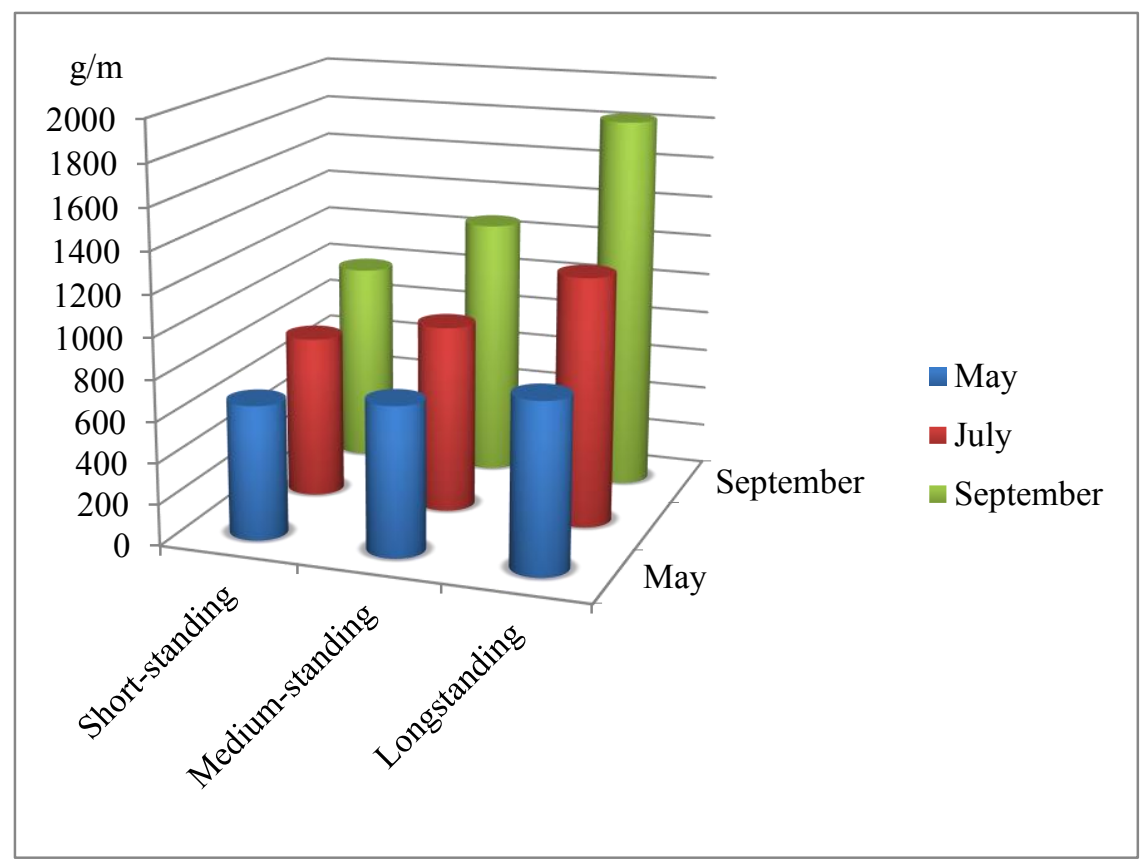

Fig. 2. The total wet weight of plants on set-asides of various ages, $\mathrm{g} / \mathrm{m}^{2},(2018-2019)$.

Considering the percentage of annual-biennial and perennial weeds growing on unevenaged set-aside lands, it can be noted that during the spring and summer period, annual (including ephemeral) and biennial weeds prevailed on all set-asides. By the autumn their number decreased by $48-41 \%$ on the short- and medium-standing set-asides due to ephemeral plants. With a decrease in the number of annual-biennial weeds, their wet weight decreased by $22-24-20 \%$ on all uneven-aged set-asides under the study. In September, the number of perennial weeds on the short- and medium-standers was $75-80 \%$. By the end of the vegetation season, the wet weight of perennials on the medium- and longstanding setasides reached $92 \%$ (table 2 ).

Table 2. Percentage of annual and perennial weeds on set-aside lands of various ages (2018-2019).

\begin{tabular}{|c|c|c|c|c|}
\hline \multirow[b]{2}{*}{ Month } & \multicolumn{2}{|c|}{ Annual weeds } & \multicolumn{2}{|c|}{ Perennial weeds } \\
\hline & Weed amount & Wet weight & Weed amount & Wet weight \\
\hline \multicolumn{5}{|c|}{ Short-standing set-aside land } \\
\hline spring - May & 73 & 52 & 27 & 48 \\
\hline summer - July & 68 & 44 & 32 & 56 \\
\hline $\begin{array}{c}\text { autumn - } \\
\text { September }\end{array}$ & 25 & 30 & 75 & 70 \\
\hline \multicolumn{5}{|c|}{ Medium-standing set-aside land } \\
\hline spring - May & 61 & 33 & 39 & 67 \\
\hline summer - July & 54 & 11 & 46 & 89 \\
\hline $\begin{array}{c}\text { autumn - } \\
\text { September }\end{array}$ & 20 & 9 & 80 & 91 \\
\hline \multicolumn{5}{|c|}{ Longstanding set-aside land } \\
\hline spring - May & 80 & 28 & 20 & 72 \\
\hline summer-July & 72 & 16 & 28 & 84 \\
\hline $\begin{array}{l}\text { autumn - } \\
\text { September }\end{array}$ & 52 & 8 & 48 & 92 \\
\hline
\end{tabular}


Flora of different vegetative mass accumulating solar energy have been formed on different set-aside agro-ecosystems. Significant accumulation of energy contributed to the decrease in entropy of the environment and the improvement of its ecological state. The analysis of Table 3 showed that the minimum accumulation of incoming energy in crops $(16914.21 \mathrm{MJ} / \mathrm{ha})$ and the minimum anti-entropic state grade (14.5 points) refer to an agroecosystem of the short-standing set-aside land. The medium-standing set-aside land accumulated 1.3 times more energy through vegetation process of its group of weeds, so its anti-entropic state gained 85.5 points. A 25 -year-old set-aside land with long-vegetating perennials growing there contributed to the maximum accumulation of energy in crops: $25712.42 \mathrm{MJ} / \mathrm{ha}$, so this parcel had the highest anti-entropic function, which was optimal in terms of solar energy usage, according to the environmental assessment (table 3).

Table 3. The influence of age of set-aside parcel on the anti-entropic state of agro-ecosystem, (20182019).

\begin{tabular}{|c|c|c|}
\hline Set-aside land & $\begin{array}{c}\text { Gross energy accumulated in corps, } \\
\mathrm{MJ} / \text { ha }\end{array}$ & Anti-entropic state, points \\
\hline Short-standing & 16914.21 & 14.5 \\
\hline Medium-standing & 21986.14 & 85.5 \\
\hline Long-standing & 25712.42 & 100.0 \\
\hline
\end{tabular}

It should be noted that an agrophytocenosis accumulates several times more solar energy than a set-aside land parcel. It was observed that cultivation of Sorghum bicolor (L.) Moench in the Volga Delta ensured the accumulation of energy in crops from 185,000 to $253,000 \mathrm{MJ} / \mathrm{ha}$, which is ten times more than weeds accumulate on longstanding set-asides.

\section{Discussion}

The problem of set-aside lands concerns various aspects: political, economic and legal. There were analyzed the hydrophysical and agrochemical parameters of the uneven setaside lands. In parallel, a study of vegetation change for various species composition was carried out. The conducted research on the changes occurring on set-aside lands are of practical and theoretical interest. The theoretical significance lies in the establishment of soil patterns in contemporary zonal conditions, as well as the study of the restoration potential of the local landscapes. The practical side is related to soil fertility problems. Over the past decade, grassland with reed, shrub and tree species was formed on the set-aside lands. Transforming such land parcels into agriculture areas will involve increased material, monetary and energy costs. Forbs persist on the set-asides, primarily because of the seeds that stay in the ground. After plowing up, the forbs should disappear from the sites. Repeated plowing, disk harrowing and hoeing of the soil should help to cope with the unwanted vegetation. As long as the soil has signs of degradation, mineral fertilizers should be applied. In the future, it is also necessary to develop a system for the use of herbicides, which includes drugs effective against the maximum spectrum of species of weed flora.

\section{Conclusions}

The conducted research states that the vegetation composition on the uneven aged set-aside lands of the research farm "Opytnoye pole" amounts to 28 species belonging to 16 families. Asteraceae (5 species), Poaceae (4 species), Brassicaceae (3 species) are classified as large families of the plant community. The remaining 13 families include from 1 to 2 species. Over a 10-year period, 3 families (Ranunculaceae, Limoniaceae, Zygophillaceae) and 25 species have thinned. The quantitative species composition of vegetation of set-aside lands 
varies depending on age: the longer the parcel is in the set-aside state, the less the number of species grows on it. During the spring period, the total amount of stems of weeds on short-standing set-aside parcels exceeds 1.5-2.0 times that of the medium- and longstanding ones. Ephemeral plant population dominates on all set-asides in the springsummer time, while perennials take over in autumn. Their amount is $75-80 \%$ for short- and medium-standing set-asides, and their wet weight reaches $70-92 \%$ due to the growth and development of the rhizome perennial - common reed. The number of weeds of the xerophyte group increases by $14-32 \%$ on medium- and long-standing set-aside land parcels. Long vegetative perennials that grow on old-aged set-asides, contribute to the maximum accumulation of energy in crops $-25712.42 \mathrm{MJ} / \mathrm{ha}$.

\section{References}

1. J. L. Rolando, C. Turin, et al., Agriculture, Ecosystems \& Environment 236, 221-233 (2017) doi.org/10.1016/j.agee.2016.12.010

2. S. Swierszcz, A. Nowak, et al., Urban Forestry \& Urban Greening. 41, 323-332 (2019) DOI: $10.1016 /$ j.ufug.2019.05.001

3. J. Liang, Xiao-an Wang, et al., Agricultural Sciences in China 9(10), 1481-1491 (2010) DOI: $10.1016 / \mathrm{S} 1671-2927(09) 60241-8$

4. J. Zhang, H. Zhao, et al., Journal of Arid Environments 62(4), 555-566 (2005) DOI: 10.1016/j.jaridenv.2005.01.016

5. J. R. Arevalo, S. Fernandez-Lugo, et al., Acta Oecologica 85, 77-84 (2017) DOI: 10.1016/j.actao.2017.09.014

6. H. Li, Yaoyang Zhao, F. Zheng, Science of The Total Environment 717, 137-149 (2020) DOI: 10.1016/j.scitotenv.2020.137149

7. M. J. Riva, I. N. Daliakopoulos, et al., Applied Geography 86, 8-21 (2017) DOI: 10.1016/j.apgeog.2017.06.017

8. Q. Xiangkun, W. Kelin, Zh. Chunhua, Ecological Engineering 54, 245-253 (2013) DOI: $10.1016 /$ j.ecoleng.2013.01.002

9. B. Liu, W. Zhao, et al., Ecological Engineering 81, 301-311 (2015) DOI: 10.1016/j.ecoleng.2015.04.014

10. J. S. Visockiene, E. Tumeliene, et al., Land Use Policy 82, 709-715 (2019) DOI: 10.1016/j.landusepol.2019.01.013

11. T. Lasanta, J. Arnaez, E. Nadal-Romero, Advances in Chemical Pollution, Environmental Management and Protection 4, 71-117 (2019) DOI: 10.1016/bs.apmp.2019.07.002

12. B. Sun, Z. Li, et al., Ecological Indicators 107, 105614 (2019) DOI: 10.1016/j.ecolind.2019.105614

13. K. Shono, S. J. Davies, et al., Forest Ecology and Management 237, 1-3, 574-582 (2006) DOI: 10.1016/j.foreco.2006.10.003

14. W. Mekuria, M. Wondie, et al., Heliyon 4(8), e00764 (2018) DOI: 10.1016/j.heliyon.2018.e00764

15. B. C. Patten, Ecological Modelling 335, 101-138 (2016) DOI: 10.1016/j.ecolmodel.2015.10.020

16. S. E. Jørgensen, S. Bastianoni, et al., A New Ecology, Systems Perspective, 7-33 (2007) DOI: 10.1016/B978-044453160-5/50002-7 